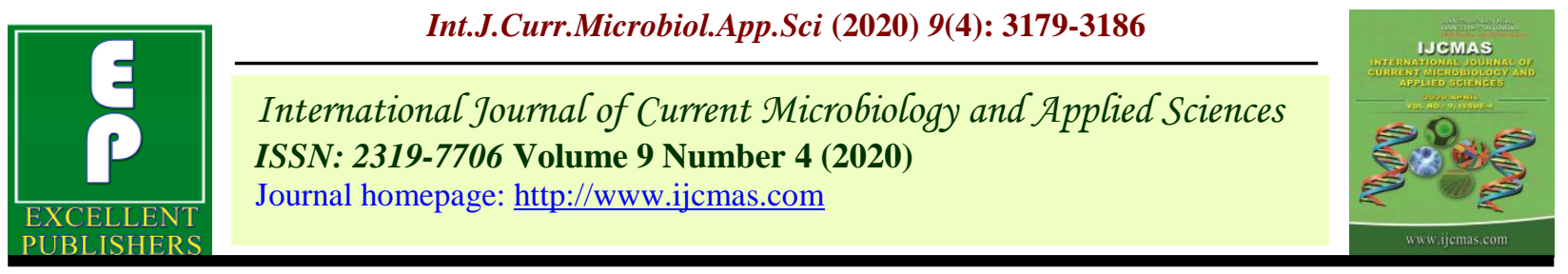

Original Research Article

https://doi.org/10.20546/ijcmas.2020.904.370

\title{
Phenotypic Stability Analysis on Macaroni Wheat (Triticum durum desf.) Under Normal and Stress Environments
}

\author{
Bhagwati Baranda* and A. K. Sharma \\ Department of Genetics and Plant Breeding, College of Agriculture, Swami Keshwanand \\ Rajasthan Agricultural University, Bikaner (Rajasthan)-334006, India \\ *Corresponding author
}

\section{A B S T R A C T}

\begin{tabular}{|l|}
\hline Ke y w o r d s \\
Durum wheat, \\
Stability \\
parameters, Grain \\
Yield, \\
Environmental \\
conditions
\end{tabular}

The experimental material comprised of 10 genotypes and 45 crosses along with two checks (HI-8627 and MPO-1215) of durum wheat. The material was evaluated under three different environments at College of Agriculture, Bikaner, during Rabi 2018-19. Analysis of variance of stability revealed that mean sum of square due to genotypes, environments and environment (Linear) were found to be significant for all the characters. It also revealed that $E+(G \times E)$ interaction components were significant for all the traits except flag leaf length and harvest index. Joint consideration of mean performance and stability parameters revealed that parent and crosses namely, NIDW-295, PDW-291 × RAJ-1555, WH-896 × NIDW-295 and HI-8663 $\times$ PDW-274 exhibiting unit regression and nonsignificant deviations suggesting average stability and wider adaptability for grain yield. However, RAJ-1555 $\times$ HI-8737 and HI-8663 $\times$ HI-8737 showed their performance in favourable environments, while PDW-274 $\times$ PDW-233, HI-8498 $\times$ RAJ-1555 and HI-8498 $\times$ PDW-274 were suitable for late sown conditions for grain yield per plant.

\section{Introduction}

Wheat is world's largest cereal crop (Dumato et al., 2015). The species of Triticum has three ploidy levels i.e. diploid $(2 n=14)$, tetraploid $(2 n=24)$ and hexaploid $(2 n=42)$. There are sixteen different species, out of which only three species are cultivated throughout the world. Durum wheat (Triticum durum Desf., $2 \mathrm{n}=4 \mathrm{x}=28$, AABB) is a tetraploid cereal crop grownup in a diverse range of climatic zones varying from warm and dry to cool and wet environments (Giraldo et al., 2016). Durum wheat is most important crop in the Mediterranean basin (Elias and Manthey, 2005), mainly in the Central and West Asia and North Africa (CWANA) region. It is serving as a naturally bi-fortified food and it is being used for "dual purpose" i.e., both for 'nutritive chapatti' and semolina required for fast food preparation, because of its high $\beta$-carotene, hectoliter 
weight, sedimentation, protein content and high level of micronutrients (Prasad et al., 2014).

The genotype $x$ environment interaction is defined as the interplay of a genotype with that of prevailing environments during its developments period. It gives an idea of stability of the population. Phenotypically stable varieties are generally pursued for commercial production of crop plants. In breeding programs, it is important to screen and identify phenotypically stable genotypes.

\section{Materials and Methods}

The present experimental material consisted of 10 parents, which were crossed in diallel fashion (excluding reciprocals) to develop forty five crosses during Rabi 2017-18. Three sets of the experiment material were sown at three different dates of sowing as $\mathrm{E}_{1}$ (early), $\mathrm{E}_{2}$ (normal) and $\mathrm{E}_{3}$ (late) of ten parents along with forty five crosses and two checks (MPO1215 and HI-8627). The experiment was laid out in randomized block design (RBD) with three replications in each environment during Rabi 2018-19. Observations were recorded for characters like days to $50 \%$ heading, days to maturity, plant height $(\mathrm{cm})$, flag leaf length $(\mathrm{cm})$, flag leaf area $\left(\mathrm{cm}^{2}\right)$, tillers plant ${ }^{-1}$, spike length $(\mathrm{cm})$, grain filling period, number of grains $\operatorname{spike}^{-1}$, grain weight $\operatorname{spike}^{-1}(\mathrm{~g})$, biological yield $\operatorname{plant}^{-1}(\mathrm{~g})$, harvest index $(\%)$, test weight $(\mathrm{g})$, protein content $(\%)$ and grain yield plant ${ }^{-1}(\mathrm{~g})$. The data were analyzed for $\mathrm{G}$ $\mathrm{x} E$ interactions and stability parameters using model of Eberhart and Russell (1966).

\section{Results and Discussion}

In the present investigation, the pooled analysis of variance for phenotypic stability for different traits clearly indicated that genotypic differences were highly significant for all the characters. The same patterns have also been observed in previous studies by
Aziz et al., (2015) and Singh et al., (2017). The mean sum of squares due to environment and environment (linear) were found to be highly significant for all the studied characters, showing differential effect of environments on the genotypes. These findings confirm the earlier research work done by Singh et al., (2013). Further the mean sum of squares due to $E+(G \times E)$ was observed highly significant for all the characters except flag leaf length and harvest index, revealing that genotypes responded differentially by planting at diverse environmental conditions. These results were also supported by Patel et al., (2014), Kumar et al., (2017) and Singh et al., (2017)

Recently, interest has been focused on regression analysis. The regression approach was first proposed by Yates and Cochran (1938) which was later modified by Finlay and Wilkinson (1963) to interpret the varietal adaption to varying environments. Regression technique was slightly improved by adding one more parameters i.e. deviation from regression by Eberhart and Russell (1966). According to them, both linear (bi) and nonlinear $\left(\mathrm{S}^{2} \mathrm{di}\right)$ function should be considered while judging the phenotypic stability of genotype.

The results of stability parameters for grain yield per plant and its related characters revealed that out of 57 genotypes, parent NIDW-295 and crosses HI-8663 × PDW-274, WH-896 $\times$ NIDW-295 and PDW-291 $\times$ RAJ1555 , expressed their stability amongst three environments due to their high grain yield per plant, regression coefficient (bi) near unity and least deviation from linear regression $\left(\mathrm{S}^{2} \mathrm{di}\right)$. These findings confirm the earlier research work done by Patel et al., (2014), Meena et al., (2014), Kumar et al., (2017) and Singh et al., (2017). The crosses namely PDW-274× PDW-233, HI-8498 × RAJ-1555, HI-8498 $\times$ PDW-274, PDW-291 $\times$ NIDW$295, \mathrm{HI}-8663 \times$ PDW-233 and WH-896 $\times$ 
PDW-274 showed high mean, above average response and non-significant $\mathrm{S}^{2} \mathrm{di}$, which revealed that these genotypes would performed well under normal environments, that in timely sown conditions. This results also supported by Kumar et al., (2014) and Kumar et al., (2017). Whereas, only two crosses HI-8663 $\times$ HI-8737 and RAJ-1555 $\times$ HI-8737 showed non-significant deviation from regression coupled with high mean value and below average response indicating their suitability and stability in poor environment. Similar findings as per Kumar et al., (2017) and Singh et al., (2018).

NIDW -295 was one of the parent for stable hybrids (PDW-291 × NIDW-295) of grain yield per plant and also showed stability for other traits like plant height, grain weight per spike and test weight. Its utilization in hybrid breeding would be useful in boosting the yield of durum wheat.

For days to $50 \%$ heading parents $\mathrm{HI}-8498$ and PDW-314 and crosses viz., HI-8498 x HI8663 and HI-8498 $x$ PDW-233, The genotypes took fewer days to maturity than general mean in which parents i.e., PDW-291, WH-896, RAJ-1555, PDW-274 and crosses namely PDW-291 $\times$ HI-8663, PDW-291 $\times$ HI-8737, HI-8498 $\times$ PDW-314, PDW-274 $\times$ HI-8737, RAJ-1555 $\times$ PDW-314, PDW-314 $\times$ HI-8737 and MPO-1215 (check) and for plant height four crosses namely PDW-291× PDW233, PDW-291 $\times$ PDW-314, HI-8663 $\times$ NIDW-295 and HI-8663 $\times$ HI-8737 based on stability parameters proved to be best under wide range of environments as they had bi values almost unity $(\mathrm{bi}=1)$ and lowest deviation from regressions $\left(\mathrm{S}^{2} \mathrm{di}\right)$ along lowest mean performance than population mean. On the other hand eight crosses for heading, one parent and two cross for maturity and four cross for plant height stable under favourable environments, while seven parent and ten cross for heading, one parent and ten cross for maturity and seven parent along nine cross were most stable under moisture stress as well as late sown conditions.

In case of flag leaf area, out of 57 genotypes, parents HI-8663, PDW-274 and crosses viz., HI-8498 x HI-8737, HI-8663 x PDW-314 and RAJ-1555 $x$ PDW-233 and PDW-314, NIDW-295 and crosses PDW-291 x PDW274, HI-8663 x RAJ-1555, HI-8663 x PDW233, HI-8663 x PDW-314, PDW-274 x PDW233 and PDW-314 x HI-8737 for grain filling period had regression coefficient (bi) near to one along superior mean performance and non-significant deviation from regression, thus possessed fair stability and wider adaptation over environments. While parent HI-8737 and nine crosses for flag leaf area and three parents namely PDW-291, HI-8494, WH-896 and eight crosses for grain filling period showed greater specificity and adaptability to high yielding environments. On the other hand three parents and nine crosses for flag leaf area and only ten crosses for grain filling period considered well suited for late sown environments.

It was revealed that parents HI-8498, HI-8663 and crosses HI-8663 x RAJ-1555, WH-896 x RAJ-1555 and WH-896 x HI-8737 for number of productive tillers per plant;HI8663 x PDW-233 and PDW-291 x PDW-274 for spike length and cross HI-8498 x NIDW295 for grain weight per spike could be responsive to across the environments and it may be considered stable for this characters in all of the environments due to bi value equal to unity with high mean values and nonsignificant deviation from regression. While six parents and seven crosses had more number of tillers, one parent HI-8498 and three crosses for spike length, In contrast three crosses for grains per spike and four crosses for grain weight per spike had bi $>1$ along high mean value and non-significant deviation $\left(\mathrm{S}^{2} \mathrm{di}\right)$ considered as adaptable to optimum environments (Table 1 and 2). 
Table.1 Analysis of variance for phenotypic stability for grain yield per plant and its components

\begin{tabular}{|c|c|c|c|c|c|c|c|}
\hline \multirow[t]{2}{*}{ Characters } & \multicolumn{7}{|c|}{ Source of variation with degree of freedom } \\
\hline & $\begin{array}{c}\text { Genotypes } \\
{[56]}\end{array}$ & $\begin{array}{c}\text { Environment } \\
{[2]}\end{array}$ & $\begin{array}{c}\text { Env. + } \\
(\text { G x E) } \\
{[114]}\end{array}$ & $\begin{array}{c}\text { Env. } \\
\text { (linear) } \\
\text { [1] }\end{array}$ & $\begin{array}{c}\mathbf{G} \times \mathbf{E} \\
\text { ( linear) } \\
{[56]}\end{array}$ & $\begin{array}{c}\text { Pooled } \\
\text { deviations } \\
{[57]}\end{array}$ & $\begin{array}{c}\text { Pooled } \\
\text { error } \\
{[342]}\end{array}$ \\
\hline Days to $50 \%$ heading & $5.21 * *$ & $2909.7 * *$ & $53.31 * *$ & $5819.41 * *$ & $3.66^{* *}$ & 0.92 & 1.2 \\
\hline Days to maturity & $15.02 * *$ & $2152.04 * *$ & $40.8 * *$ & $4304.08 * *$ & $4.59 * *$ & 1.57 & 0.81 \\
\hline Plant height (cm) & 7.13 & $3416.31 * *$ & $65.81 * *$ & $6832.62 * *$ & $7.24 *$ & 4.63 & 1.78 \\
\hline Flag leaf length $(\mathrm{cm})$ & $4.14 * *$ & $57.61 * *$ & 2.36 & $115.22 * *$ & 0.84 & 1.87 & 0.97 \\
\hline Flag leaf area $\left(\mathrm{cm}^{2}\right)$ & $7.42 * *$ & $208.83 * *$ & $5.17 * *$ & $417.66 * *$ & 1.42 & 1.62 & 1.76 \\
\hline $\begin{array}{c}\text { Number of productive tillers per } \\
\text { plant }\end{array}$ & $7.37 * *$ & $214.34 * *$ & $4.46^{* *}$ & $428.68 * *$ & 0.61 & 0.79 & 0.41 \\
\hline Spike length $(\mathrm{cm})$ & $2.01 * *$ & $7.17 * *$ & $0.42 * *$ & $14.34 * *$ & $0.4 * *$ & 0.19 & 0.11 \\
\hline Grain filling period & $23.09 * *$ & $770.03 * *$ & $15.67 * *$ & $1540.05^{* *}$ & $3.63 * *$ & 0.76 & 1.09 \\
\hline Number of grains per spike & $168.99 * *$ & $811.67 * *$ & $38.16^{* *}$ & $1623.35^{* *}$ & $35.52 * *$ & 12.94 & 1.32 \\
\hline Grain weight per spike (g) & $0.61 * *$ & $1.83 * *$ & $0.12 * *$ & $3.65^{* *}$ & $0.13^{* *}$ & 0.04 & 0.01 \\
\hline Biological yield per plant (g) & $36.93 * *$ & $2660.02 * *$ & $59.32 * *$ & $5320.04 * *$ & $17 * *$ & 8.6 & 1.34 \\
\hline Harvest index (\%) & $110.62 * *$ & $99.71 *$ & 28.22 & $199.42 * *$ & 30.89 & 22.6 & 3.07 \\
\hline Test weight (g) & $60.07 * *$ & $174.15^{* *}$ & $11.74 * *$ & $348.31 * *$ & $13.48 * *$ & 4.13 & 0.96 \\
\hline Protein content $(\%)$ & $0.55^{* * *}$ & $14.97 * *$ & $0.47 * *$ & $29.95 * *$ & $0.31^{* *}$ & 0.11 & 0.01 \\
\hline Grain yield per plant (g) & $24.6^{* *}$ & $521.28 * *$ & $12.38 * *$ & $1042.57 * *$ & 3.37 & 3.16 & 0.31 \\
\hline
\end{tabular}

$*$ and $* *$ represents significant at $5 \%$ and $1 \%$ level of significance, respectively 
Table.2 Response of top five stable parents and crosses to the environments for different traits

\begin{tabular}{|c|c|c|c|}
\hline \multirow[t]{2}{*}{ Characters } & \multicolumn{3}{|c|}{ Genotypes } \\
\hline & Average environment (bi = 1) & Favorable environment (bi > 1) & Unfavorable environment (bi < 1) \\
\hline $\begin{array}{l}\text { Days to } 50 \% \\
\text { heading }\end{array}$ & $\begin{array}{l}\text { HI-8498, PDW-314, } \\
\text { HI-8498 } \times \text { PDW-233, HI-8498 } \times \text { HI- } \\
8663\end{array}$ & $\begin{array}{l}\text { PDW-274 × HI-8737, HI-8498 × PDW-274, } \\
\text { WH-896 × RAJ-1555, HI-8498 × RAJ-1555 } \\
\text { HI-8498 × NIDW-295, }\end{array}$ & $\begin{array}{l}\text { WH-896, RAJ-1555, PDW-233, PDW- } \\
274, \text { PDW-291, PDW-291 × WH-896, } \\
\text { HI-8663 × RAJ-1555, HI-8663 × } \\
\text { NIDW-295, PDW-233 × HI-8737, } \\
\text { RAJ-1555 × HI-8737 }\end{array}$ \\
\hline $\begin{array}{ll}\text { Days to } \\
\text { maturity }\end{array}$ & $\begin{array}{l}\text { PDW-291, WH-896, RAJ-1555, PDW- } \\
\text { 274, MPO-1215 (check), PDW-291 × } \\
\text { HI-8737, PDW-291 × HI-8663, RAJ- } \\
1555 \times \text { PDW-314, HI-8498 } \times \text { PDW-314, } \\
\text { PDW-274 } \times \text { HI-8737, }\end{array}$ & $\begin{array}{l}\text { NIDW-295, WH-896 × PDW-314, } \\
\text { PDW-291 × HI-8498 }\end{array}$ & $\begin{array}{l}\text { HI-8737, WH-896 × RAJ-1555, RAJ- } \\
1555 \times \text { HI-8737, WH-896 } \times \text { NIDW-295, } \\
\text { RAJ-1555 } \times \text { PDW-233, WH-896 } \times \\
\text { PDW-274, }\end{array}$ \\
\hline $\begin{array}{l}\text { Plant height } \\
\text { (cm) }\end{array}$ & $\begin{array}{l}\text { PDW-291× PDW-314, HI-8663 × HI- } \\
8737, \\
\text { HI-8663 × NIDW-295, PDW-291 } \times \\
\text { PDW-233, }\end{array}$ & $\begin{array}{l}\text { HI-8498 } \times \text { NIDW-295, HI-8498 } \times \text { PDW }- \\
233, \\
\text { PDW-291× RAJ-1555, HI-8663 } \times \text { PDW }- \\
274\end{array}$ & $\begin{array}{l}\text { NIDW-295, HI-8663, PDW-233, HI- } \\
8737, \text { HI-8498, HI-8498 } \times \text { PDW-314, } \\
\text { PDW-233 } \times \text { HI-8737, PDW-233 } \times \\
\text { PDW-314, PDW 233 } \times \text { NIDW-295, } \\
\text { PDW- } 274 \times \text { PDW-233, }\end{array}$ \\
\hline $\begin{array}{l}\text { Flag leaf area } \\
\left(\mathrm{cm}^{2}\right)\end{array}$ & $\begin{array}{l}\text { HI-8663, PDW-274, RAJ-1555 × PDW- } \\
233, \\
\text { HI-8498 } \times \text { HI-8737, HI-8663 × PDW- } \\
314\end{array}$ & $\begin{array}{l}\text { HI-8737, PDW-291 × HI-8737, PDW-274 } \times \\
\text { PDW-233, HI-8498 } \times \text { RAJ-1555, } \\
\text { RAJ-1555 } \times \text { NIDW-295, RAJ-1555 } \times \\
\text { PDW-314, }\end{array}$ & $\begin{array}{l}\text { PDW-291, HI-8498, WH-896, HI-8498 } \\
\times \text { HI-8663, PDW-291 × RAJ-1555, } \\
\text { HI-8498 × PDW-233, WH-896 } \times \\
\text { NIDW-295, } \\
\text { HI-8663 } \times \text { RAJ-1555, }\end{array}$ \\
\hline $\begin{array}{l}\text { Number of } \\
\text { productive } \\
\text { tillers plant }^{-1}\end{array}$ & $\begin{array}{l}\text { HI-8663, HI-8498, } \\
\text { WH-896 × HI-8737, } \\
\text { WH-896 × RAJ-1555, } \\
\text { HI-8663 × RAJ-1555, }\end{array}$ & $\begin{array}{l}\text { PDW-274, PDW-291, HI-8663, RAJ-1555, } \\
\text { PDW-233, PDW-291 × HI-8737, } \\
\text { HI-8498 × HI-8663, PDW-274 × PDW-233, } \\
\text { PDW-291 × RAJ-1555, PDW-291 × HI- } \\
8663,\end{array}$ & PDW-314, HI-8498 × PDW-233 \\
\hline $\begin{array}{l}\text { Spike length } \\
\text { (cm) }\end{array}$ & $\begin{array}{l}\text { HI-8663 × PDW-233, } \\
\text { PDW-291 × PDW-274, }\end{array}$ & $\begin{array}{l}\text { HI-8498, PDW-291 × HI-8737, } \\
\text { HI-8663 × HI-8737, } \\
\text { WH-896 × RAJ-1555, }\end{array}$ & $\begin{array}{l}\text { HI-8663, PDW-291 × RAJ-1555, } \\
\text { HI-8498 × PDW-233, } \\
\text { PDW-291 × HI-8498, }\end{array}$ \\
\hline
\end{tabular}




\begin{tabular}{|c|c|c|c|}
\hline $\begin{array}{l}\text { Grain filling } \\
\text { period }\end{array}$ & $\begin{array}{l}\text { PDW-314, NIDW-295, PDW-274 } \times \\
\text { PDW-233, PDW-291 × PDW-274, } \\
\text { HI-8663 } \times \text { RAJ-1555, HI-8663 } \times \text { PDW- } \\
314, \\
\text { PDW-314 } \times \text { HI-8737 }\end{array}$ & $\begin{array}{l}\text { PDW-274, HI-8663 } \times \text { PDW-274, PDW- } \\
233, \\
\text { HI-8663 } \times \text { NIDW-295, HI-8498 } \times \text { HI-8663, } \\
\text { PDW-291 × WH-896, PDW-233 × PDW- } \\
314\end{array}$ & $\begin{array}{l}\text { PDW-314 } \times \text { NIDW-295, PDW-291 } \times \\
\text { HI-8498, PDW-233 } \times \text { HI-8737, } \\
\text { NIDW-295 } \times \text { HI-8737, HI-8498 } \times \\
\text { NIDW-295 }\end{array}$ \\
\hline $\begin{array}{l}\text { Number of } \\
\text { grains spike }^{-1}\end{array}$ & - & $\begin{array}{l}\text { PDW-291 × HI-8737, HI-8663 × PDW-274, } \\
\text { HI-8663 × HI-8737 }\end{array}$ & HI-8498, HI-8498 × PDW-233 \\
\hline $\begin{array}{l}\text { Grain weight } \\
\text { spike }^{-1}(g)\end{array}$ & HI-8498 × NIDW-295 & $\begin{array}{l}\text { PDW-291 × HI-8737, HI-8663 × RAJ-1555 } \\
\text { WH-896 × RAJ-1555, PDW-291 × PDW- } \\
274,\end{array}$ & $\begin{array}{l}\text { HI-8498, HI-8663, HI-8663 × PDW- } \\
274, \text { PDW-274 × PDW-233, PDW-291 } \\
\times \text { RAJ-1555, HI-8498 × PDW-233, } \\
\text { PDW-291 × HI-8663, }\end{array}$ \\
\hline $\begin{array}{l}\text { Biological } \\
\text { yield plant } \\
\text { (g) }\end{array}$ & $\begin{array}{l}\text { PDW-274 } \times \text { PDW-233, HI-8663 } \times \text { RAJ- } \\
1555, \text { RAJ-1555 } \times \text { PDW-274 }\end{array}$ & $\begin{array}{l}\text { PDW-314, HI-8498 } \times \text { PDW-233, PDW-233 } \\
\times \text { PDW-314, HI-8498 } \times \text { PDW-274, } \\
\text { HI-8663 } \times \text { PDW-233, }\end{array}$ & $\begin{array}{l}\text { PDW-274, HI-8663 × PDW-274, } \\
\text { PDW-291 × HI-8498, PDW-291 × RAJ- } \\
1555, \text { PDW-314 } \times \text { HI-8737, PDW-233 } \\
\times \text { NIDW-295 }\end{array}$ \\
\hline $\begin{array}{l}\text { Test weight } \\
\text { (g) }\end{array}$ & HI-8498 × NIDW-295 & $\begin{array}{l}\text { HI-8663 } \times \text { RAJ-1555, HI-8663 } \times \text { HI-8737, } \\
\text { WH-896 } \times \text { RAJ-1555, PDW-291 } \times \text { PDW- } \\
274\end{array}$ & $\begin{array}{l}\text { HI-8498, HI-8663 × PDW-274, PDW- } \\
291 \times \text { RAJ-1555, HI-8498 } \times \text { PDW-233, } \\
\text { PDW-291 × HI-8663 }\end{array}$ \\
\hline $\begin{array}{l}\text { Protein } \\
\text { content }(\%)\end{array}$ & - & $\begin{array}{l}\text { WH-896, HI-8663 } \times \text { WH-896, PDW-291 } \times \\
\text { HI-8663, PDW-274 } \times \text { HI-8737, } \\
\text { RAJ-1555 } \times \text { NIDW-295, RAJ-1555 } \times \\
\text { PDW-274, }\end{array}$ & - \\
\hline $\begin{array}{l}\text { Grain yield } \\
\text { plant }^{-1}(\mathrm{~g})\end{array}$ & $\begin{array}{l}\text { NIDW-295, PDW-291 × RAJ-1555, } \\
\text { HI-8663 × PDW-274, WH-896 × NIDW- } \\
295\end{array}$ & $\begin{array}{l}\text { PDW-274 × PDW-233, HI-8498 × RAJ- } \\
1555, \\
\text { HI-8498 } \times \text { PDW-274, PDW-291 } \times \text { NIDW- } \\
295, \text { HI-8663 } \times \text { PDW-233 }\end{array}$ & $\begin{array}{l}\text { RAJ-1555 × HI-8737, HI-8663 × HI- } \\
8737\end{array}$ \\
\hline & se stability) & $\begin{array}{l}\mu, b_{i}>1 \text { and } S^{2} d_{i}=0 \\
>\mu, b_{i}<1 \text { and } S^{2} d_{i}=0 \\
b_{i}=1 \text { and } S^{2} d_{i}=0\end{array}$ & \\
\hline
\end{tabular}


The genotypes that were responsive to adverse environments (drought) were PDW314 and HI-8498 x PDW-233 for tillers, parent HI-8663 and crosses namely PDW-291 x HI-8498, PDW-291 x RAJ-1555 and HI$8498 \times$ PDW-233 for spike length, parent HI8498, cross HI-8498 x PDW-233 and check HI-8626 for grains per spike and two parents as well as five crosses were found stable under low yielding environments, as these had regression coefficient less than unity $(\mathrm{bi}<1)$ with high mean value and non-significant $S^{2}$ di values.

Studied 57 genotypes for biological yield per plant in which three crosses namely HI-8663 $x$ RAJ-1555, RAJ-1555 x PDW-274 and PDW-274 x PDW-233 and HI-8498 x NIDW295 for test weight These genotypes were considered as wider adaptable and most stable across three environments on account of its average response due to non-significant deviation $\left(\mathrm{S}^{2} \mathrm{di}\right)$ with regression coefficient around unity (bi=1) and high mean value as comparison to general mean,

While one parent along four crosses for biological yield and only four crosses for test weight had predictable behavior under below average stability, revealing their suitability and stability under rich environments. However, one parent along five crosses for both biological yield and test weight showed below responsiveness as they had suited for saline and stressed environments.

Quality parameters protein content observed that out of fifty seven genotypes, parents WH896 and crosses viz., PDW-291 x HI-8663, HI-8663 x WH-896, RAJ-1555 x PDW-274, RAJ-1555 x NIDW-295, PDW-274 x HI8737 and check HI-8626 registered higher mean than general mean with regression coefficient greater than unity and least deviation of $S^{2}$ di. Therefore these genotypes could perform under better environmental conditions.
Conclusion is as follows, From the foregoing discussion, it is clear from stability behavior performance, that genotypes NIDW-295, HI$8663 \times$ PDW-274 and PDW-291 $\times$ RAJ-1555 were stable over environment. However, RAJ-1555 × HI-8737 and HI-8663 × HI-8737 were stable in favourable environments but PDW-274 × PDW-233, HI-8498 × RAJ-1555 HI-8498 $\times$ PDW-274 were suitable in unfavourable environments for grain yield and its contributing characters besides above which revealed that stability is imparted by its component traits should be given due importance while formulating breeding programme aiming to develop high yielding and stable hybrids in durum wheat.

\section{References}

Aziz, O. K., Mustafa K. M., Kareem H. S. S. and Rash H. H. (2015). Genotype x Environment interaction and Stability Analysis for Yield in Durum Wheat. The Iraqi Journal of Agricultural Sciences, 46(6):6906-6691.

Dumato, D., Alamerew, S., Eticha, F. and Assefa, E. (2015). Genetic variability in bread wheat (Triticum aestivum L.) germplasm for yield and yield component traits. J. Biol. Agril. and Healthcare, 5:140-147.

Eberhart, S. A. and Russell, W. A. (1966). Stability parameters for comparing varieties. Crop Science, 6:36-40.

Elias, E. M. and Manthey, F. A. (2005). End products: present and future uses. In: Royo, C., Nachit, M. M., DiFonzo, N., Araus, J. L., Pfeiffer, W.H., Slafer, G.A. (Eds.), Durum Wheat Breeding Current Approaches and Future Strategies. Food Products Press, New York, pp. 63-86.

Finlay, K. W and Wilkinson, G. N. (1963).The analysis of adaptation in a plant breeding programme. Aust. $J$ Agric. Res., 1963; 14(6):742-754.

Giraldo, P., Royo, C., GonzaAlez, M., 
Carrillo, J. M. and Ruiz, M. (2016).Genetic diversity and association mapping for agromorphological and grain quality traits of a structured collection of durum wheat landraces including subsp. durum, turgidumand diccocon.PLoS1 (11).

Kumar, A., Kumar, P., Singh, G. and Tiwari, K. N. (2017).Stability analysis for different agromorphological traits under different temperature regimes in bread wheat (Triticum aestivum L.). Res. Environ. Life Sci., 10(3): 270-274.

Patel, B. C., Rojasara, Y. M., Akbari, V. R. and Patel, J. A. (2014). Stability analysis for grain yield in bread wheat (Triticum aestivum L.) for irrigated ecosystems. J. Wheat Research, 6(2):160-162.

Prasad, S. V., Dubey, V. G., Ambati, D., Prakash, T. L. and Mishra, A. N. (2014). Poshan A Healthy Alternative. Agric Today, pp 38-39.

Singh, A. G., Saini, L., Saini, H. and Sharma, A. K. (2017). Estimation of stability parameters for seed yield and its components in triticale and wheat genotypes under potimim and stress environments. International, Journal of Chemical Studies., 5(4):708-7012.

Singh, S. V., Yadav, R. K. and Ram, D. N. (2013).Stability analysis for comparing wheat genotypes. Bharatiya Krishi Anusandhan Patrika, 28:65-70.

Yates, F. and Cochra, W. G. (1938).The analysis of groups of experiments. $J$ Agril. Sci., 28(4):556-580.

Meena, H. S., Kumar, D., Srivastava, S. and Prasad, R. (2014).Stability for grain yield and its contributing traits in bread wheat (Triticum aestivum L.). The Indian J. Agril.Scie., 84(12).

Kumar, V., Tyagi, B. S. Verma, A. and Sharma, I. (2014). Stability analysis for grain yield and its components under different moisture regimes in bread wheat (Triticum aestivumL.). The Indian J. Agril. Sci., 84(8).

Singh, C., Srivastava, P., Sharma, A., Kumar, P., Chhuneja, P., Sohu V. S. and Bains N.S. (2018). Stability analysis for grain yield and some quality traits in bread wheat (Triticum aestivum L.). J. Applied and Natural Science, 10(1): 466- 474.

\section{How to cite this article:}

Bhagwati Baranda and Sharma, A. K. 2020. Phenotypic Stability Analysis on Macaroni Wheat (Triticum durum desf.) Under Normal and Stress Environments. Int.J.Curr.Microbiol.App.Sci. 9(04): 3179-3186. doi: https://doi.org/10.20546/ijcmas.2020.904.370 